\title{
NÁVRH DÍLČÍ KONCEPCE SYSTÉMU BENEFITNÍHO ODMĚŇOVÁNÍ ZAMĚSTNANCŮ VE VÝROBNÍM PODNIKU NA PRINCIPECH CAFETERIA SYSTÉMU
}

\author{
Radim řihák
}

Klíčová slova:

Cafeteria systém, podnik, zaměstnanec, koncepce, koeficient, zaměstnanecký benefit

\section{Key words:}

Cafeteria system, enterprise, employee, conception, coefficient, employee benefit

\begin{abstract}
Abstrakt
Článek svým obsahem analyzuje a poukazuje na důležitost sestavení transparentního a přehledného systému benefitního odměňování pracovníků uplatnitelného v praxi. Ve své podstatě se zabývá návrhem koncepce systému benefitního odměňování zaměstnanců založeném na principech cafeteria systemu. Koncepce byla vytvořena na základě výzkumu realizovaného v konkrétním výrobním podniku a je postavena na jednotlivých specifických benefitních blocích. Každý z nich pak v určité míre zohledňuje postoj zaměstnance k pracovnímu procesu a jeho přístup $\mathrm{k}$ dalším definovaným parametrům. Koncepce také poukazuje na postoj zaměstnavatele $\mathrm{k}$ danému zaměstnanci, vyjádřený výší celkové hodnoty benefitů pro každého z nich za určité období. Tento benefitní system je významným nástrojem pro dosažení vyšší efektivity v podniku.
\end{abstract}

\begin{abstract}
The article analyzes and highlights the importance of drawing up a transparent and clear system of benefit remuneration that is applicable in practice. In its essence, the article deals with the draft of a sub-concept of the system of benefit remuneration of employees based on the principles of cafeteria system. The concept was created on the basis of research done in a particular manufacturing company and it is based on individual specific benefit blocks. Each of them then reflects a certain degree of employee attitude to the work process and his/her approach to other defined parameters. The concept also refers to the attitude of the employer to the employee, expressed in the total value of benefits for each employee in a certain period of time. This benefit system is an important tool for achieving greater efficiency in the company.
\end{abstract}

\section{Úvod}

Systém benefitního odměňování zaměstnanců v podnicích, stejně jako samotná role a působnost HR oddělení v jednotlivých společnostech, prochází za poslední roky výraznými proměnami, a to především vlivem dopadů celosvětového hospodářského vývoje na podnikatelskou sféru. Pro efektivní, transparentní a současně motivující benefitní systém odměňování je třeba jednotlivé benefitní položky (portfolio) sestavit tak, aby následné čerpání zaměstnaneckých výhod bylo pro pracovníka stimulující, oslovující a v konečné fázi se neminulo smyslem a účinkem, a to jak z pohledu mnímání zaměstnanci, tak z pohledu zaměstnavatele. Řešení, respektive neřešení, těchto zásadních otázek a strategicky důležitých přístupů v podniku může mít následně podstatný vliv a dopad jak na pracovní prostředí (a tedy samotného zaměstnan- 
ce, jeho míru loajality k zaměstnavateli, př́ístup k pracovnímu životu), tak potažmo na působení daného podniku a míru jeho konkurenceschopnosti na domácích a zahraničních trzích.

Účelem následujícího textu není předložení analýzy nákladů spojené s detailní predikcí vývoje čerpání jednotlivých benefitních položek zaměstnanci výrobního podniku, ani legislativní či daňové vymezení navrhovaných benefitů s ohledem na způsob jejich čerpání a podobně. Článek má za cíl poukázat na potřebu vyváženosti jednotlivých způsobů (forem) poskytování benefitů, přičemž hlavní důraz je kladen na návrh dílčí koncepce systému benefitního odměňování pracovníků ve výrobním podniku založeném na principech cafeteria systému s jeho částečnou modifikací, představený na modelové situaci podniku DR, a. s.

\section{Systémy benefitního odměňování zaměstnanců podniku}

Systémy benefitního odměňování mají v mnoha podnicích řadu podob a modifikací, přičemž nejdůležitější je, aby zavedený systém nepozbýval na své funkčnosti, transparentnosti a byl efektivním, propracovaným systémem nepř́ímo podporujícím motivaci pracovníků a mimo jiné i jejich loajalitu, spokojenost a sounáležitost s podnikem. Po provedení analýzy vhodnosti (možnosti) zavedení nového systému benefitního odměňování v daném podniku je třeba jeho novou koncepci řádně představit a detailně popsat tak, aby se řadoví pracovníci seznámili s její podstatou - tedy, aby se implementace systému principiálně neminula účinkem.

\subsection{Cafeteria systém - flexibilní systém benefitního odměňování}

Cafeteria systém benefitního odměňování nabízí pracovníkovi možnost, „aby si vybíral zpravidla z několika nabídek vhodně sestavených souborü zaměstnaneckých výhod (menu). (Koubek, 2009). Odklon od tradičních metod mzdové politiky a snaha o individuálně strukturovaný př́jem za vykonanou práci činí z tohoto systému inovační prvek v odměňování s přitažlivou perspektivou dalšího rozvoje. ${ }^{1}$ Jeho efektivní uplatnění je ovšem závislé na kvantifikaci vzájemné převoditelnosti prakticky všech personálních nákladů, přičemž předpoklady účinného fungování jsou spatřovány:

- $\quad$ p provádèní pravidelného průzkumu motivační struktury zaměstnanců;

- ve sledování vývoje u konkurence, jaké mzdy a benefity poskytuje;

- v aktualizování nabídky zaměstnaneckých výhod;

- v průběžném informování pracovníků o zaměstnaneckých výhodách, ale také firemních nákladech na ně vynakládaných, aby príjemce těchto požitkủ lépe pochopil, jakou sociální péči mu zaměstnavatel věnuje;

- $\quad v$ zavedení agendy pro sledování čerpání zvýhodnění jednotlivými zaměstnanci (a s tím spojené organizační a technické zajištění poskytování). (Smrčeková, 2004).

Vnímání preferencí zaměstnanců je velmi důležité. Systém benefitního odměňování by měl fungovat jako částečně či zcela volitelný, přičemž na základě akceptace preferencí může podnik úspěšně dospět k tomu, že ,je vytvořena paleta možností, z nichž si zaměstnanec (při dodržení rámcových parametrů) může sám vybírat; zaměstnanci pocházejí z rozdílných věkových, sociálně, či jinak zájmově orientovaných skupin, kde má každý jinou prioritu svých sociálních potřeb. Dochází tak k pevnějšímu sepětí se strategickými a taktickými záměry personální politiky zaměstnavatele s cílem důstojnější motivace zaměstnanců. " (Pelc, 2009). Důležitým předpokladem fungování systému flexibilních zaměstnaneckých výhod je, aby

\footnotetext{
${ }^{1}$ Podrobněji ŘIHÁK, R. Benefitní systém odměňování - kafeteria - efektivní přístup k zaměstnaneckým výhodám nejen v období hospodářského útlumu. In Sborník z mezinárodní Bat’ovy konference pro doktorandy a mladé védecké pracovníky. Zlín: UTB FAME, 2010. ISBN 978-80-7318-922-8. „Zaměstnanecké výhody, můžeme charakterizovat jako benefity, zahrnujicí širokou paletu požitků - tj. zboží, služeb či forem péče o zaměstnance - poskytovaných organizací, za které by zaměstnanec musel jinak platit. “(Armstrong, 1999).
} 
„náklady na plánování, administrativu, nižši hospodárnost při opatřování malého souboru zaměstnaneckých výhod i efektivní komunikaci nepřevážily potenciální úspory. “ (Pala, 2002).

\section{Návrh dílčí koncepce systému benefitního odměňování zaměstnanců ve výrobním podniku DR, a. s.}

Pro následující (prezentovanou) modelovou situaci budeme uvažovat o regionálně významném výrobním (strojírenském) podniku DR, a. s. ${ }^{2}$, se sídlem v České republice, který se v rámci organizační struktury člení do 5 podnikových divizí s celkovým počtem 206 zaměstnanců. V podniku bude uplatňován benefitní systém odměňování - odvíjející se od principů cafeteria systému a taktéž od specifických managementem stanovených mimořádných benefitů (za zaměstnancovo vynikající nasazení při pracovním výkonu pro podnik). V návrhu dílčí koncepce je zohledňováno pracovní zařazení zaměstnance do jedné ze tř́i vytvořených skupin (viz text dále). Taktéž je třeba nový systém benefitního odměňování uvést v soulad s vymezenými podmínkami a pravidly pro poskytování a čerpání zaměstnaneckých výhod stanovených jak samotným podnikem, tak platnými zákonnými ustanoveními. Obecně se za racionální a výhodný považuje postup, kdy je před implementací nového systému v podniku mezi pracovníky realizováno dotazníkové šetření, v němž může respondent vyjádřit míru spokojenosti se současným systémem benefitního odměňování, míru spokojenosti s rozsahem portfólia zaměstnaneckých výhod, jež má možnost čerpat před realizací změn(y) v systému. Taktéž by měl mít zaměstnanec možnost vyjádřit svůj názor, zda by uvítal rozšíření nabídky benefitů a o jaké zaměstnanecké výhody by měl případně zájem. Nejen na základě výše uvedeného musí management podniku zvážit aktuální situaci a rozhodnout se, zda upřednostní fungování stávajícího systému odměňování i nadále, či provede dílčí změny, nebo systém úplně obmění (nahradí). V neposlední řadě je rozhodující ekonomická stránka, resp. alokace finančních zdrojů do HR oblasti v podniku, a s tím související uplatňovaná personální politika a naplňování strategických cílů podniku. Nemalou roli hraje také fakt, jak př́ihodná jsou v dané situaci legislativní ustanovení pro zaměstnavatele (vztahující se právě k poskytování benefitů) a pro zaměstnance (vztahující se k čerpání benefitů). Systém odměňování musí ve své podstatě pokrýt působnost všech zaměstnanců podniku a taktéž v určité míře reflektovat pracovní výkon každého $\mathrm{z}$ nich tak, aby byl pro pracovníka motivující a zároveň transparentní a konkurenceschopný, vyvážený a spravedlivý. V uvažovaném podniku DR, a. s. byli pro účely návrhu koncepce systému odměňování pracovníci rozděleni do tří skupin:

1. skupina - „Kategorie D“ v počtu 130 zaměstnanců. Jedná se o pracovníky působící ve výrobě (manuální práce), vyjma vybraných pracovníků zařazených do 2 . skupiny;

2. skupina - „Technicko-hospodářští pracovníci (THP) + vybraní (pro podnik významní) pracovníci kategorie $\mathbf{D}^{\text {“ }} \mathrm{v}$ celkovém počtu 70 zaměstnanců;

3. skupina - „Představitelé top managementu podniku“ o celkovém počtu 6 manažerů.

Po provedené analýze vhodnosti zavedení nového systému benefitního odměňování (metodou dotazování), vyhodnocení finanční situace v podniku (především v HR oblasti) a na základě predikce vývoje HR trendů, zejména $\mathrm{v}$ oblasti benefitního odměňování, vyhodnotil autor článku společně s představiteli top managementu podniku za nejvíce vyhovující př́ístup

\footnotetext{
${ }^{2}$ Název podniku byl z důvodu požadavku na uchování jeho anonymity pozměněn (ze strategických důvodů); výzkumné šetření, mapující míru spokojenosti pracovníků v oblasti benefitního odměňování v DR, a. s. (včetně analýzy možnosti změn v systémových přístupech v oblasti benefitního odměňování), proběhlo mezi zaměstnanci podniku (technikou dotazníku) na základě kvótního výběru respondentů ze základního souboru (206 pracovníků). Výsledky šetření stejně jako realizované konzultace s představiteli managementu DR, a. s. byly přínosnými ve vztahu k mávrhu dílčí koncepce systému benefitního odměňování uváděné v tomto článku.
} 
cafeteria systém - formy jádra s její modifikací. Nabídka benefitů v této formě jádra je rozčleněna na pevnou složku (jádro) a pohyblivou složku (volitelný blok), přičemž část systému benefitního odměňování bude založena taktéž na odměnách a příspěvcích poskytovaných zaměstnancům ve výjimečných (individuálně posuzovaných) případech, a to za pracovníkův mimořádný přínos či výkon odvedený pro podnik, prričemž tento mimořádný benefit bude zaměstnanci poskytnut výhradně na základě rozhodnutí top managementu společnosti.

\subsection{Systém jádra - PEVNÝ blok}

Pevný blok tvoří benefity, na jejichž čerpání dosáhne každý ze zaměstnanců podniku, a to na základě splnění obecných podmínek ${ }^{3}$ vyplývajících z pracovně-právního vztahu zaměstnance se zaměstnavatelem, přičemž peněžitá hodnota daného benefitů (resp. míra jeho poskytnutí) je pro všechny zaměstnance podniku stejná. Zájmem podniku je tedy poskytnout benefity, které jsou pro zaměstnance přínosné (bez ohledu na jejich věk, pohlaví, vzdělání či pracovní zařazení). Vedení společnosti současně usuzuje nutnost nabídnutí vybraných benefitů z důvodu:

- prevence proti úrazům, nemocem a chorobám, včetně možnosti finančního zajištění v neproduktivním věku pracovníka; snahy o snížení absence zaměstnanců;

- solidárnosti a pomoci zaměstnanci a jeho rodině v tíživých životních situacích;

- zájmu o ochranu zdraví při práci a zlepšení podmínek jak v pracovním, tak v osobním životě zaměstnance a jeho rodiny.

V rámci koncepce cafeterie - pevného bloku - byla v podniku DR, a. s. navržena struktura zaměstnaneckých výhod (viz Tabulka 1) pro všechny zaměstnance podniku. Jednotlivé benefitní položky mohou tedy čerpat „zaměstnanci kategorie D“; „TH pracovníci + vybraní zaměstnanci kategorie D“ a ,představitelé top managementu“.

Tabulka 1: Pevný blok

\begin{tabular}{|c|c|c|c|}
\hline \multicolumn{4}{|c|}{$\begin{array}{c}\text { "Přehled nabizených zaměstnaneckých benefitú v DR, a.s. “ } \\
\text { PEV N } \mathrm{Y} \text { B O K - cafeterie (systém jádra) }\end{array}$} \\
\hline $\begin{array}{l}\text { Dílčí položky pevného bloku cafeteria systému } \\
\text { pro všechny zaměstnance } D R \text {, a. s. }\end{array}$ & $\begin{array}{l}\text { Zaměstnanci } \\
\text { „kategorie } D^{“}\end{array}$ & $\begin{array}{l}\text { Nižší a střední management } \\
\text { TH pracovníci + vybraní } \\
\text { zaměstnanci „,kategorie } D^{\star c}\end{array}$ & $\begin{array}{l}\text { Top } \\
\text { management }\end{array}$ \\
\hline B E N E F I T & \multicolumn{3}{|c|}{$\begin{array}{l}\text { ROČ́Ní suma (v KČ) připadajícína } \\
\text { jednoho zaměstnance }\end{array}$} \\
\hline Přispěvek na penzijní připojištěni ${ }^{1}$ & až 6000 ,- & až 6000 ,- & až 6000 ,- \\
\hline Přispěvek na soukromé životní pojištěni ${ }^{2}$ & $3600,-$ & $3600,-$ & $3600,-$ \\
\hline Úhrada úrokủ ze sociální pủjčky na překlenutí tíživé finanční situace & až $1600,-$ & až $1600,-$ & až 1600 ,- \\
\hline Týden dovolené nad rámec zákonných předpisů & plně hrazeno & plně hrazeno & plně hrazeno \\
\hline Vstupní lékařská prohlídka zaměstnance & plně hrazeno & plně hrazeno & plně hrazeno \\
\hline Příspěvek na stravné $-55 \% \mathrm{z}$ ceny poskytované stravenky & hrazeno & hrazeno & hrazeno \\
\hline "Zdravotní péče“ - dispenzámí prohlídky, mimořádné (nařizené) prohlídky & plně hrazeno & plně hrazeno & plně hrazeno \\
\hline $\begin{array}{l}\text { Příspěvek v rámci: pracovního jubilea zaměstnance, životního jubilea, uzavření } \\
\text { sňatku, narození potomka(ů), úmrti zaměstnance či jeho rodinného př̌slušnika }\end{array}$ & plně hrazeno & plně hrazeno & plně hrazeno \\
\hline Služební automobil s možností jeho využivání pro soukromé účely & - & - & hrazeno \\
\hline Mobilní telefon s možností jeho využivání pro soukromé účely & - & - & hrazeno \\
\hline Firemní notebook s možností jeho využivání pro soukromé účely & - & - & plně hrazeno \\
\hline
\end{tabular}

Zdroj: Vlastní zpracování

\footnotetext{
${ }^{3}$ Obecnými podmínkami se rozumí: uzavření pracovního poměru na dobu určitou či neurčitou (benefitní systém neakceptuje DPP, DPČ); podnikem stanovené období, po které musí být zaměstnanec v pracovním poměru v podniku; neprovinění se proti pracovnímu řádu, směrnicím (například krádež v prostorách DR, a. s.) a jiné.
} 


\subsection{Systém jádra - VOLITELNÝ blok}

Zaměstnanci DR, a. s. (výše rozděleni do tří skupin) mají možnost čerpat benefity v rámci volitelného bloku, a to ze tří benefitních podskupin, ve ketrých jsou nabízeny konkrétní výhody (s hodnotovým peněžním vyjádřením ${ }^{4}$ u většiny z nich). Každá z těchto podskupin má svá specifika pro čerpání a taktéž diferencovaná pravidla a podmínky, jejichž splnění zaměstnanci umožňuje čerpání výhod. Volitelný blok tedy pracovníkovi nabízí svobodu rozhodování (možnost výběru) mezi nabízenými položkami při akceptování stanoveného hodnotového stropu (maximální částky), do něhož může zaměstnanec benefity volit a kombinovat dle svých osobních preferencí. Tato forma je považována za kompromisní řešení mezi svobodnou volbou pracovníka a podnikovou odpovědností.

\subsubsection{První benefitní podskupina volitelného bloku}

První podskupina volitelného bloku obsahuje zaměstnanecké výhody, které mohou čerpat dle svobodné volby všichni zaměstnanci podniku dle vlastních preferencí, přičemž pro příslušnou skupinu (do níž je pracovník zařazen) je stanovena odlišná hodnotová (peněžní) výše, stejně tak jako pro danou benefitní položku. První podskupina volitelného bloku obsahuje zaměstnanecké výhody (viz Tabulka 2), přičemž záměrem zaměstnavatele je razantně eliminovat návyky (kouření cigaret) u konkrétních pracovníků, jež mohou mít následně vliv na jejich pracovní výkon a mají negativní dopad na využití fondu pracovní doby. Záměrem zaměstnavatele je taktéž nabídnout prríspěvek na očkovací vakcínu proti chřipce či příspěvek na zdravotnické služby poskytované nad rámec zdravotní péče hrazené zdravotní pojišt'ovnou těm zaměstnancům, kteří mají o daný benefit zájem, resp. jejich zdravotní stav si to vyžaduje. Zaměstnavatel také zohledňuje nutnost dopravy do/ze zaměstnání a nabízí možnost volby benefitu a následného čerpání př́íspěvku na dopravu. Pracovník může v rámci čerpání dalšího z nabídky benefitů - „Sick Day“ - využít absentování v práci pro vyřízení si osobních záležitostí během pracovní doby, přičemž jeho nepřítomnost bude zaměstnavatelem plně hrazena.

Tabulka 2: Volitelný blok - I. benefitní podskupina

\begin{tabular}{|c|c|c|c|}
\hline \multicolumn{4}{|c|}{$\begin{array}{c}\text { "Přehled nabizených zaméstnaneckých benefit ů v DR, a.s. " } \\
\text { VOLITEL N Ý B L K - cafeterie (systém jádra) }\end{array}$} \\
\hline $\begin{array}{l}\text { Dílčí položky volitelného bloku, které mají možnost } \\
\text { čerpat všichni zaměstnanci DR, a. s., dle jejich } \\
\text { svobodného rozhodnutí, po splnění pravidel pro jejich } \\
\text { čerpání, do stanovené výše. }\end{array}$ & $\begin{array}{l}\text { Zaměstnanci } \\
\text { „kategorie } D^{4}\end{array}$ & $\begin{array}{l}\text { Nižši a střední } \\
\text { management } \\
\text { „TH pracovníci + vybraní } \\
\text { zaměstnanci kategorie } \mathrm{D}^{\star *}\end{array}$ & Top management \\
\hline (1) & \multicolumn{3}{|c|}{$\begin{array}{l}\text { ROČNÍ suma (v Kč) připadající na jednoho } \\
\text { zaměstnance }\end{array}$} \\
\hline 1. benefitní podskupina & $2000,-$ & $4000,-$ & $6000,-$ \\
\hline Přispěvek na protikuřáckou léčbu zaměstnance & $1000,-$ & $2000,-$ & $5500,-$ \\
\hline $\begin{array}{l}\text { Přsspěvek na zdravotnické služby poskytované nad rámec zdravotní péče } \\
\text { hrazené zdravotní pojištơvnou }\end{array}$ & $1000,-$ & 2000 & $5500,-$ \\
\hline Přispěvek na očkovací vakcínu proti chřipce & $300,-$ & $300,-$ & $300,-$ \\
\hline $\begin{array}{c}\text { Přispěvek na pojištění odpovědnosti za škody způsobené zaměstnancem } \\
\text { zaměstnavateli }\end{array}$ & $700,-$ & $500,-$ & $500,-$ \\
\hline Přispěvek na dopravu zaměstnance do/ze zaměstnání & až 1000 ,- & až 1500 ,- & --- \\
\hline „Sick Day““ - volný den - omluvená absence zaměstnance s náhradou mzdy & $\begin{array}{c}1 \text { den } \\
\text { plně hrazen }\end{array}$ & $\begin{array}{l}1 \text { den } \\
\text { plně hrazen }\end{array}$ & $\begin{array}{c}1 \text { den } \\
\text { plně hrazen }\end{array}$ \\
\hline
\end{tabular}

Zdroj: Vlastní zpracování

\footnotetext{
${ }^{4} \mathrm{~V}$ př́ípadě, že u daného benefitu není stanovena konkrétní hodnota v Kč, je tento benefit ošetřen jiným uvedeným způsobem - nap̌r. identifikací „,plně hrazen“. U benefitu „Sick Day“ není peněžitá hodnota benefitu záměrně uvedena; jedná se vždy o „specifickou výši“ hodnoty benefitu, odvíjející se od konkrétního zaměstnance.
} 


\subsubsection{Druhá benefitní podskupina volitelného bloku}

Druhá podskupina dílčí koncepce obsahuje benefitů (Tabulka 6), jejichž nárok na čerpání se odvíjí od plnění specifických podmínek stanovených podnikem. Přihlíží se k pracovníkovu odvedenému výkonu za dané období a především se zohledňuje zaměstnancův postoj k práci a svěřeným úkolům, jeho disciplinovanost a $\mathrm{v}$ neposlední řadě se bere $\mathrm{v}$ potaz pracovníkův význam (nepostradatelnost) pro podnik.

Koncept cafeterie kalkuluje $\mathrm{v}$ této benefitní podskupině s bodovým hodnocením každého jednotlivce a evidencí tzv. „osobního účtu zaměstnance“. Na tento účet se pracovníkovi dle stanoveného klíče připisují body, přičemž od počtu bodů dosažených za stanovené období pak zaměstnanci vzniká (či nevzniká) nárok na možnost čerpání jednotlivých benefitů z této druhé podskupiny. Na základě konzultací s mistry jednotlivých divizí podniku DR, a. s. byla stanovena určitá kritéria hodnocení pro následné přidělování bodů, jež zohledňují pracovníkův odvedený výkon a další parametry pracovního jednání. Zaměstnanec je hodnocen za určené období přímým nadřízeným (daným mistrem, případně odpovědným manažerem divize, resp. ředitelem akciové společnosti) - dle konkrétní pracovní pozice, kterou zastává v organizační struktuře DR a. s. Nadřízený pracovník hodnotí daného zaměstnance dle jednotlivých stanovených kritérií (viz Tabulka 3) na hodnotící škále vymezené 0 až $100 \%$, přičemž součet dílčích hodnot (vyjádřených v \%) se dělí počtem hodnotících kritérií. Takto dosažená průměrná procentuální hodnota představuje dílčí hodnocení zaměstnancova pracovního př́ístupu k práci za dané období. Hodnocení daného zaměstnance je možné a vhodné provádět za stanovené období vícekrát (modelová situace uvažuje období jednoho kvartálu), přičemž je na managementu podniku, v jakých intervalech a s jakou pravidelností bude hodnocení zaměstnanců provádět. Dílčí průměrné procentuální hodnoty (za každé realizované hodnocení) se po uplynutí hodnotícího období (kvartálu) sečtou a vydělí aktuálním počtem realizovaných zjištění.

Tabulka 3: Hodnocení zaměstnance DR, a. s. (pro druhou benefitní podskupinu volitelného bloku)

\begin{tabular}{|c|c|c|c|}
\hline $\begin{array}{l}\text { Pořadové } \\
\text { číslo }\end{array}$ & $\begin{array}{l}\text { Kritéria pro hodnocení } \\
\text { zaměstnancova postoje k práci }\end{array}$ & $\begin{array}{c}\text { Zaměstnanec } \\
\text {,kategorie D“6 } \\
\text { (hodnocení v \%) }\end{array}$ & $\begin{array}{c}\text { THP pracovník + zaměst- } \\
\text { nanec ,kategorie D“6 } \\
\text { (hodnocení v \%) }\end{array}$ \\
\hline 1. & Kvalita odvedené práce & $0-100 \%$ & $0-100 \%$ \\
\hline 2. & Plnění pokynů nadřízeného & $0-100 \%$ & $0-100 \%$ \\
\hline 3. & $\begin{array}{l}\text { Využití fondu pracovní doby } \\
\text { zaměstnancem (kuřák/nekuřák) }\end{array}$ & $0-100 \%$ & $0-100 \%$ \\
\hline 4. & $\begin{array}{l}\text { Technická zdatnost, samostatnost } \\
\text { zaměstnance při pracovním výkonu }\end{array}$ & $0-100 \%$ & $0-100 \%$ \\
\hline 5. & Dodržování parametrů ISO 9001 & $0-100 \%$ & ---- \\
\hline 6. & $\begin{array}{l}\text { Dodržování parametrů EMS (ochrana } \\
\text { životního prostředí při výrobním procesu) }\end{array}$ & $0-100 \%$ & ---- \\
\hline 7 & Užívání nástrojů, pracovních pomůcek & $0-100 \%$ & ---- \\
\hline 8. & $\begin{array}{c}\text { Specifické ohodnocení pracovníka } \\
\text { jeho přímým nadřízeným }\end{array}$ & $0-100 \%$ & ---- \\
\hline
\end{tabular}

Zdroj: Vlastní zpracování

Kritéria hodnocení zaměstnance DR, a. s. se zaměřují na komplexní přístup zaměstnance ke svěřeným pracovním úkolům, povinnostem, pracovnímu výkonu, kdy je zohledňováno osm, resp. čtyři, specifické skutečností, a na základě jejich plnění je zaměstnanec svým nadřízeným pracovníkem ohodnocen a je mu připsán na jeho „osobní účet“ určitý počet bodů představující po přepočtu určitou peněžitou hodnotu v Kč. Tímto hodnocením (a následným benefitním 
odměněním) management podniku nehodlá nijak omezovat či znevýhodňovat své zaměstnance, či jiným způsobem předurčovat jejich svobodné rozhodnutí pro konkrétní benefit. Podstata významu benefitního odměňování zůstává zachována, význam (míra důležitosti) daného zaměstnance pro zaměstnavatele a jeho sounáležitost $\mathrm{s}$ podnikem je $\mathrm{v}$ tomto volitelném bloku podporována právě zvýhodňováním jemu přidělovaných bodů ošetřených př́íslušným koeficientem, a to za předpokladu, že své kvality, výjimečnost, disciplinovanost a v neposlední řadě významnost pro podnik demonstruje svým plnohodnotným kvalitním pracovním životem.

První zohledňované kritérium, od něhož se odvíjí hodnocení pracovníka, je „kvalita odvedené práce“", kdy je zjišt’ována míra zmetkovosti výrobků, na níž se pracovník svým odvedeným výkonem podílel; u TH pracovníků se přístup k hodnocení kvality odvedené práce odvíjí od povahy (specifičnosti) vykonávané práce. Druhým kritériem je „plnění pokynů nadřízeného“ za sledované hodnocené období. Stanovení kritéria „využití fondu pracovní doby zaměstnancem“ bere v potaz pracovníkovo plnění či neplnění pracovního plánu, dodržování či nedodržování stanovených termínů a další skutečnosti s tím související; demonstruje také zájem podniku potlačit návyk (závislost) pracovníka na návykové látce (na nikotinu - specifikace v DR, a. s.) a potažmo zajistit efektivnější využívání pracovní doby. Kritérium „technická zdatnost, samostatnost zaměstnance při pracovním výkonu“ zohledňuje kladný prŕístup zaměstnance k svěřeným pracovním úkolům a činnostem, nezatěžování ostatních pracovníků či svého nadřízeného dotazy s požadavkem na objasnění problematiky a podobně. Kritérium „dodržování parametrů ISO 9001“ má za cíl poukázat na důležitost faktoru kvality výrobku namísto případného záměru či snahy pracovníka o docílení co nejvyšší produkce v rámci svého výkonu za dané období. Šetrnost zaměstnance k životnímu prostředí při výrobním procesu je reflektována kritériem „dodržování parametru EMS“5. Autor př́íspěvku, společně s představiteli managementu DR, a. s., vyhodnotil za opodstatněný taktéž způsob „užívání nástrojů, pracovních pomůcek“ při výrobním procesu a míru jejich poškození (vyřazení) vlivem nedůsledného užívání a zacházení. Vhodným kritériem se také jeví „specifické ohodnocení pracovníka jeho přímým nadřízeným“, kdy nadřízený pracovník má možnost zohlednit další nedefinované př́stupy a situace, přičemž je tímto kritériem ošetřena situace prostojů spolupracovníků, jež se podílí na výrobě daného výrobku a tudíž až následně po jejich pracovním přičinění se výrobek dostává k danému pracovníkovi. Tento subjektivní pohled nadřízeného může negativní dopady vyvstalých specifik zohlednit a zmírnit.

Každý pracovník může za stanovené období (kvartál) dosáhnout na různý počet bodů, ošetřený př́íslušným koeficientem, přičemž management podniku stanovuje hodnotou koeficientu (vyššího, resp. nižšího, než hodnota 1,0) mezník, od něhož dochází při přepočtu získaných bodů $^{6}$ příslušným koeficientem ke zvýšení či snížení celkové sumy získaných bodů - viz skupiny $1 \mathrm{ex}$ (do této skupiny zařazen zaměstnanec, jehož pracovní př́stup k práci byl ohodnocen hodnocením „excelentní“); 2vb (hodnocení „,výborný“); 3ch (hodnocení „,chvalitebný“); 4pr (hodnocení „,průměrný“); 5pd (hodnocení „,podprůměrný“). U takto dosažených bodů (ošetřených prŕíslušným koeficientem) je následně zohledněna docházka zaměstnance do práce, a to způsobem, kdy je suma dosažených bodů vydělena konstantní hodnotou 60,0 a následně vynásobena počtem dní, po které byl zaměstnanec za dané období (kvartál) přítomen v práci. Poté je takto dosažená hodnota bodů přepočtena na základě př́islušné korunové sazby za jeden

\footnotetext{
${ }^{5}$ EMS - systém environmentálního řízení, kde si podnik klade za cíl systematický př́ístup k ochraně životního prostředí ve všech směrech při své podnikatelské činnosti.

${ }^{6}$ Diference mezi „získanými“ a „dosaženými“ body: „Získanými body“ se rozumí body, jež byly pracovníkovi přiděleny za dané pracovní období (tzn. 1000 bodů, resp. 2000 bodů); „dosaženými“ body se rozumí body navýšené příslušným(i) koeficientem(ty) na základě zaměstnancova pracovního přičinění, tj. pracovník tedy dosáhl svým pozitivním/negativním přístupem k práci navýšení/snížení počtu bodů.
} 
bod (odvislé od stupně hodnocení) do peněžního vyjádření (v Kč). Zaměstnanec disponující aktuální sumou dosažených prostředků si poté svobodně (dle preferencí) volí jednotlivé benefitní položky z této druhé podskupiny, a to až do vyčerpání sumy prostředkủ. V konečném důsledku může tedy pracovník dosáhnout vyšší bodové hodnoty, a to díky zodpovědnému, kvalitnímu pracovnímu výkonu, plnění stanovených hodnotících kritérií a svědomité docházce do práce. Záměrem DR, a. s. je zohlednit v první řadě kvalitního zodpovědného pracovníka možností adekvátního benefitního odměnění, a to dle jeho svobodné volby a možnosti výběru benefitů v částkách, jež korespondují s aktuálním stavem jeho osobního účtu.

Management podniku, resp. přímý nadřízený daného pracovníka, zaměstnance hodnotí za určité období na základě plnění stanovených kritérií. Pokud se hodnocený hrubě proviní proti pracovnímu řádu či jiným stanoveným předpisům, pravidlům a ustanovením, nemá nárok výběru (čerpání) benefitních položek za příslušné období z této druhé benefitní podskupiny. ${ }^{7}$

Tabulka 4: Stupně hodnocení ${ }^{8}$ pracovního přístupu k práci daného zaměstnance

\begin{tabular}{|c|c|c|c|}
\hline $\begin{array}{l}\text { Označení } \\
\text { přístupu } \\
\text { k práci }\end{array}$ & $\begin{array}{l}\text { Hodnocení zaměstnancova } \\
\text { pracovního přístupu (jeho } \\
\text { nadřízeným za dané období) }\end{array}$ & $\begin{array}{l}\text { Zaměstnanci ,kategorie } \\
\text { D“6 připsáno } 1000 \text { bodù } \\
\text { násobených koeficientem }\end{array}$ & $\begin{array}{c}\text { „THP nebo vybranému zaměst- } \\
\text { nanci kategorie D“ připsáno } \\
2000 \text { bodů násobených koefici- } \\
\text { entem }\end{array}$ \\
\hline $1 \mathrm{ex}$ & $\begin{array}{l}\text { excelentní (jednotlivá kritéria } \\
\text { splněna z více jak } 90 \% \text { ) }\end{array}$ & $\mathrm{k}_{\mathrm{d} 1}=1,90$ & $\mathrm{k}_{\mathrm{t} 1}=1,90$ \\
\hline $2 \mathrm{vb}$ & $\begin{array}{l}\text { výborný (jednotlivá kritéria } \\
\text { splněna z } 81 \% \text { až } 90 \% \text { ) }\end{array}$ & $\mathrm{k}_{\mathrm{d} 2}=1,40$ & $\mathrm{k}_{\mathrm{t} 2}=1,40$ \\
\hline $3 \mathrm{ch}$ & $\begin{array}{l}\text { chvalitebný (jednotlivá kritéria } \\
\text { splněna ze } 71 \% \text { až } 80 \% \text { ) }\end{array}$ & $\mathrm{k}_{\mathrm{d} 3}=1,00$ & $\mathrm{k}_{\mathrm{t} 3}=1,00$ \\
\hline $4 \mathrm{pr}$ & $\begin{array}{l}\text { průměrný (jednotlivá kritéria } \\
\text { splněna z } 61 \% \text { až } 70 \% \text { ) }\end{array}$ & $\mathrm{k}_{\mathrm{d} 4}=0,70$ & $\mathrm{k}_{\mathrm{t} 4}=0,70$ \\
\hline $5 \mathrm{pd}$ & $\begin{array}{c}\text { podprůměrný (jednotlivá kritéria } \\
\text { splněna z } 1 \% \text { až } 60 \% \text { ) }\end{array}$ & $\mathrm{k}_{\mathrm{d} 5}=0,00$ & $\mathrm{k}_{\mathrm{t} 5}=0,00$ \\
\hline
\end{tabular}

Zdroj: Vlastní zpracování

Vzorce pro výpočet dosažených bodů:

Zaměstnanec ,kategorie D“ - pro stupně hodnocení excelentní, výborný, chvalitebný:

$\mathbf{d}_{\mathbf{d}}=\mathbf{z} * \frac{\left(\mathbf{k}_{\mathbf{d}(1,2,3)}+\mathbf{k}_{\mathbf{z v}}\right)}{60} * \mathbf{c}$

Zaměstnanec ,kategorie $\mathbf{D}^{\text {“ }}$ - pro stupeň hodnocení průměrný:

$\mathbf{d}_{\mathbf{d}}=\mathbf{z} * \frac{\mathbf{k}_{\mathbf{d}(4)}}{\mathbf{6 0}} * \mathbf{c}$

,TH pracovník či vybraný zaměstnanec kategorie $D^{“ 6}$

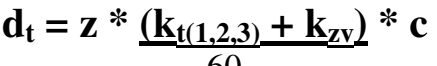

60

,TH pracovník či vybraný zaměstnanec kategorie $\mathrm{D}^{\text {“6 }}$

$\mathbf{d}_{\mathbf{t}}=\mathbf{z} * \frac{\mathbf{k}_{\mathbf{t}(4)}}{60} * \mathbf{c}$

$\mathrm{d}_{\mathrm{d}}=$ celkový počet dosažených bodů příslušného „,zaměstnance kategorie D“

$\mathrm{d}_{\mathrm{t}}=$ celkový počet dosažených bodů př́slušného „TH pracovníka či vybraného zaměstnance kategorie D“

$\mathrm{z}=$ počet získaných (přidělených) bodů za příslušné hodnocené období

$\mathrm{k}_{\mathrm{d}}=$ koeficient pro zaměstnance „,kategorie D“

\footnotetext{
${ }^{7}$ Konkrétní znění vymezujících ustanovení spadá do kompetence managementu podniku. Může se jednat např́iklad o: neomluvenou absenci zaměstnance; prokázání hladiny alkoholu v krvi či vliv návykových látek; odcizení nebo prokazatelný pokus o odcizení jakékoliv součásti majetku DR, a. s. či čehokoliv jiného, co má společnost ve svém držení apod., či se nachází v jejím areálu; pravomocné odsouzení zaměstnance za úmyslný trestný čin; oznámení od České správy sociálního zabezpečení, že zaměstnanec porušil léčebný režim a jiné.

${ }^{8} \mathrm{~V}$ rámci hodnocení zaměstnancova pracovnímu př́ístupu mu je nadřízeným přidělen jeden z uvedených stupnů.
} 
$\mathrm{k}_{\mathrm{t}}=$ koeficient pro „TH pracovníky + vybrané zaměstnance kategorie D“

$\mathrm{k}_{\mathrm{zv}}=$ zvýhodněný koeficient $^{9}\left(\mathrm{k}_{\mathrm{zv}}=0,30\right)$

$\mathrm{c}=$ počet pracovních dní za dané období (kvartál), po které byl zaměstnanec v práci

Podprůměrně hodnocený zaměstnanec ztrácí nárok na čerpání zaměstnaneckých výhod v rámci druhé benefitní podskupiny volitelného bloku. Podstata poskytování zaměstnaneckých výhod však není eliminována; zaměstnanci zůstává nárok na čerpání benefitů dle stanovených podmínek, z první a (případně) třetí podskupiny volitelného bloku, stejně tak jako benefitů z pevného bloku. V případě, že pracovník dosáhl za aktuální období (kvartál) opětovného hodnocení stupněm excelentní, či stupněm výborný, počet získaných bodů (1000, resp. 2000) se mu násobí hodnotou aktuálně př́íslušného koeficientu navýšeného o hodnotu + 0,30. Pokud stejného hodnocení dosáhne zaměstnanec i v dalším kvartálu (tj. po uplatnění zvýhodněného koeficientu), zvýhodněný koeficient se mu již nenavyšuje, zůstává na stejné hodnotě. ${ }^{10}$ Dosažený počet bodů (odvíjející se od prríslušného koeficientu, př́ípadného zvýhodnění $+0,30$ a docházky zaměstnance do práce za hodnocené období) se poté převede do korunového vyjádření (v Kč). Suma prostředků v Kč, kterou může zaměstnanec disponovat, se ve výsledném výpočtu zaokrouhlí na celá sta směrem nahoru.

Tabulka 5: Sazba (s) v Kč za 1 dosažený bod

\begin{tabular}{|c|c|c|}
\hline $\begin{array}{c}\text { Sazba za } 1 \text { bod (v Kč) u úrovně } \\
\text { hodnocení }\end{array}$ & $\begin{array}{c}\text { s (pro zaměstnance } \\
\text { „kategorie D“) }\end{array}$ & $\begin{array}{c}\text { s (pro TH pracovníky + vybrané zaměst- } \\
\text { nance kategorie D) }\end{array}$ \\
\hline 1ex (excelentní) & $1,70,-$ & $2,00,-$ \\
\hline 2vb (výborný) & $1,30,-$ & $1,60,--$ \\
\hline 3 ch (chvalitebný), 4pr (průměrný) & $1,00,-$ & $1,00,-$ \\
\hline
\end{tabular}

Zdroj: vlastní zpracování

Vzorce pro vyjádření peněžní hodnoty dosažených bodů:

$\mathbf{m}_{\mathrm{d}}=\mathbf{d}_{\mathbf{d}} * \mathrm{~s}$

$\mathbf{m}_{\mathbf{t}}=\mathbf{d}_{\mathbf{t}} * \mathbf{s}$

$\mathrm{m}_{\mathrm{d}}=$ suma prostředků, kterou má $\mathrm{k}$ dispozici „,zaměstnanec kategorie $\mathrm{D}^{\text {“ }}$

$\mathrm{d}_{\mathrm{d}}=$ celkový počet dosažených bodů př́slušného „zaměstnance kategorie $\mathrm{D}^{\text {“ }}$

$\mathrm{s}=$ hodnota v Kč připadající na jeden dosažený bod (odvislá od stupně hodnocení pracovníka)

$\mathrm{m}_{\mathrm{t}}=$ suma prostředků, kterou má $\mathrm{k}$ dispozici „TH pracovník či vybraný zaměstnanec kategorie $\mathrm{D}^{\text {“ }}$

$\mathrm{d}_{\mathrm{t}}=$ celkový počet dosažených bodů př́slušného „TH pracovníka či vybraného zaměstnance kategorie D“

Flexibilita a variantnost tohoto prezentovaného systému benefitního odměňování $\mathrm{v}$ rámci druhé benefitní podskupiny tkví v možnosti libovolného nastavení korunové sazby za jeden bod, stejně tak v možnosti úpravy hodnoty koeficientů sloužících pro výpočet sumy dosažených bodů u daného pracovníka. Podnik tak může pružně reagovat na aktuální ekonomickou situaci, výši finančních prostředků přidělených do oblasti benefitního odměňování apod. Je pochopitelné, že ne všichni zaměstnanci DR, a. s. budou hodnoceni stupněm vyšším (lepším) než stupeň ,průměrný“, který představuje zmiňovaný mezník. V případě, že zaměstnanec dosáhne na nižší počet bodů, z důvodu hodnocení stupněm ,průměrný“ (s hodnotou koeficientu 0,70 ), bude po přepočtu do peněžité formy tato suma prostředků pro čerpání benefitů přirozeně $\mathrm{v}$ nižší hodnotě a tím pádem zaměstnanec bude také omezen ve výběru zaměstnaneckých výhod vlivem disponování s nižším rozpočtem. Nedosáhne tedy například na některé $\mathrm{z}$ benefitů, jejichž peněžité vyjádření je ve srovnání s jeho aktuálním rozpočtem $\mathrm{v}$ poměrově vyšších hodnotách. Naopak v př́ípadě pozitivního (lepšího) hodnocení zaměstnance jeho př́mým nadřízeným, může dojít $\mathrm{k}$ nárůstu získaných bodů vlivem přidělení příslušného koeficientu (s hodnotou vyšší než 1,0), či dokonce koeficientu zvýhodněného o hodnotu $+0,30$. Každý zaměstnanec má tedy možnost ovlivnit výši svého aktuálního

\footnotetext{
${ }^{9}$ Zvýhodněný koeficient $\mathrm{k}_{\mathrm{zv}}=0,30$ se aplikuje výhradně u stupňủ hodnocení excelentní, výborný.

${ }^{10}$ Uplatnění zvýhodněného koeficientu na konci čtvrtého kvartálu (na přelomu kalendářního roku) je přípustné.
} 
rozpočtového omezení (výši prostředků) a taktéž výběr konkrétní benefitní položky z portfolia. Aktuální výše prostředků se odvíjí právě od pracovníkova postoje k přiděleným úkolům, jeho disciplinovanosti, přístupu ke svěřeným nástrojům, pomůckám, k zohledňování kvality a ochrany životního prostředí, dodržování interních předpisů a dalších ustanovení. V neposlední řadě je tento systém dobrým vodítkem pro ovlivnění loajality zaměstnance, jeho pracovních návyků a potažmo zvýšení spokojenosti s působením v podniku a formování podnikové kultury. Pracovník má možnost dosáhnout na značnou sumu prostředků, jež jsou mu k dispozici a může tedy zhodnotit svoji svědomitou práci vyšším příjmem (nad rámec výše vyplácené měsíční mzdy), a to ve výši až několika tisíc korun za rok. Má také možnost čerpat př́islušný počet „Sick Days“, jako jednu z forem nepeněžního benefitního plnění, či další nenárokové položky a zvýhodnění, včetně mimořádných benefitů uvedených ve třetí benefitní podskupině. Druhá benefitní podskupina volitelného bloku tedy obsahuje položky, jež jsou hodnotově diferencovány a zohledňují tak rozdělení zaměstnanců podniku do skupin. Kompletní výčet benefitů druhé podskupiny je uveden $v$ Tabulce 6 .

Tabulka 6: Volitelný blok - II. benefitní podskupina

\begin{tabular}{|c|c|c|c|c|c|}
\hline \multicolumn{6}{|c|}{$\begin{array}{c}\text { "Přehled nabizených zaměstnaneckých benefitů v DR, a.s. “ } \\
\text { VOLITEL NÝ B L OK- cafeterie (systém jádra) }\end{array}$} \\
\hline $\begin{array}{c}\text { Portfolio benefitư s př́slušnou hodnotovouvýší } \\
\text { (v Kč), na které mưže zaměstnanec dosáhnout } \\
\text { za čtvrtletí (kvartál) }\end{array}$ & \multicolumn{2}{|c|}{ Zaměstnanci „kategorie D“ } & \multicolumn{2}{|c|}{$\begin{array}{c}\text { Nižši a střední management } \\
\text { "TH pracovnici + vybrani } \\
\text { zaměstnanci kategorie D“ }\end{array}$} & \multirow{2}{*}{\begin{tabular}{|c} 
Top \\
management
\end{tabular}} \\
\hline II. benefitní podskupina & $\begin{array}{c}\text { hodnoty } \\
\text { benefitül}^{1}(\mathrm{v} \text { Kč }) \\
\text { pro lex, } 2 \mathrm{vb}\end{array}$ & $\begin{array}{l}\text { hodnoty } \\
\text { benefitü }{ }^{2}(\mathrm{v} \text { K ̌ }) \\
\text { pro } 3 \mathrm{ch}, 4 \mathrm{pr}\end{array}$ & \begin{tabular}{|c|} 
hodnoty \\
benefitü $^{3}(\mathrm{v}$ Kč $)$ \\
pro lex, 2vb
\end{tabular} & $\begin{array}{c}\text { hodnoty } \\
\text { benefitü }{ }^{4}(\mathrm{v} \mathrm{KC \check {c } )} \\
\text { pro } 3 \mathrm{ch}, 4 \mathrm{pr}\end{array}$ & \\
\hline Přispěvek na rekondiční a rehabilitační služby & $500,-$ & $400,-$ & $1000,-$ & $600,-$ & $\ldots$ \\
\hline Prisspěvek na rekreaci & $1400,-$ & $1000,-$ & $1500,-$ & $1400,-$ & $\ldots$ \\
\hline Přispěvek na lázeňskou péči & $1400,-$ & $700,-$ & $1000,-$ & $1400,-$ & - \\
\hline Přispěvek na dioptrické brỵ́le či kontaktní čočky & $500,-$ & $400,-$ & $900,-$ & $500,-$ & - \\
\hline Poskytováni permanentek na plavecký bazén & $400,-$ & $300,-$ & $300,-$ & $300,-$ & - \\
\hline Přspěvek na jazykové kurzy mimo pracoviště & $1400,-$ & $700,-$ & $1500,-$ & $1400,-$ & - \\
\hline Přispěvek na pripojení internetu $\mathrm{z}$ domova & $400,-$ & $300,-$ & $300,-$ & $300,-$ & - \\
\hline Předplatné odborných periodik & $500,-$ & $300,-$ & $1000,-$ & $900,-$ & - \\
\hline Poskytování permanentek do Fit centra & $500,-$ & $300,-$ & $500,-$ & $500,-$ & - \\
\hline Př̀spěvek na „zážitkový benefit“ (dle aktuální nabidky) & $1400,-$ & $1000,-$ & $1500,-$ & $1400,-$ & - \\
\hline „Sick Day“ - volný den - omluvená absence zaměstnance s náhradou mzdy & $\begin{array}{c}2 \text { dny } \\
\text { plně hrazeny }\end{array}$ & $\begin{array}{c}1 \text { den } \\
\text { plně hrazen }\end{array}$ & $\begin{array}{c}2 \text { dny } \\
\text { plně hrazeny }\end{array}$ & $\begin{array}{c}1 \text { den } \\
\text { plně hrazen }\end{array}$ & - \\
\hline \multicolumn{6}{|c|}{ 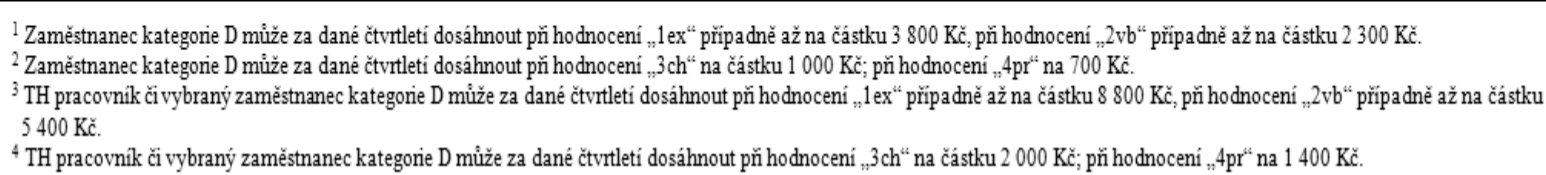 } \\
\hline
\end{tabular}

Zdroj: Vlastní zpracování

\subsubsection{Třetí benefitní podskupina volitelného bloku}

Třetí podskupina volitelného bloku nabízí možnost přidělení „,mimořádných výhod“", na jejichž čerpání (Tabulka 7) by mohl zaměstnanec dosáhnout a byly by mu poskytnuty v případě odvedení výjimečného výkonu pro podnik, poskytnutí zlepšovacího návrhu, zapř́íčinění se o přínos pro podnik a podobně. Jde o benefity demonstrující důležitost a význam daného zaměstnance pro podnik. U benefitů $\mathrm{v}$ rámci této třetí podskupiny, jež byly součástí i předešlého systému benefitního hodnocení v podniku DR, a. s., se již nejedná o vyčíslení konkrétních hodnot v Kč u každého z nich. Vychází se z obsahu interních předpisů podniku (např. pravidel ekonomického řízení, kolektivní smlouvy, resp. z titulu rozhodnutí řídících pracovníků, ředitelů divizí, potažmo ředitele společnosti), přičemž jednotlivé mimořádné 
benefity jsou dále specifikovány, resp. je tímto dána možnost individuálního př́ístupu managementu ke každému zaměstnanci. Management zohledňuje pracovníkův mimořádný přínos pro podnik, jeho angažovanost či tvůrčí schopnosti.

Tabulka 7: Volitelný blok - III. benefitní podskupina

\begin{tabular}{|c|c|c|c|}
\hline \multicolumn{4}{|c|}{$\begin{array}{c}\text { "Přehled nabizených zaméstnaneckých benefitů v DR, a.s. " } \\
\text { VOLITEL N Ý B L O K - cafeterie (systém jádra) }\end{array}$} \\
\hline MIMOŘÁDNÉ benefity & $\begin{array}{l}\text { Zaměstnanci „,kategorie } \\
D^{\text {“ }}\end{array}$ & $\begin{array}{l}\text { Nižší a střední management } \\
\text { "TH pracovníci + vybraní } \\
\text { pracovníci kategorie D" }\end{array}$ & $\begin{array}{l}\text { Top } \\
\text { management }\end{array}$ \\
\hline IIl. benefitní podskupina & \multicolumn{3}{|c|}{$\begin{array}{l}\text { Hodnotová výše benefitu (v Kč) pripadající na jednoho zaměstnance - na } \\
\text { základě rozhodnutí managementu DR, a. s. }\end{array}$} \\
\hline Příspěvek nad rámec poskytovaného soukromého životního pojištění & Individuálnè (min. 300,-) & Individuálnè (min. 600,-) & $\begin{array}{l}\text { Individuálně } \\
(\text { min.1 000,-) }\end{array}$ \\
\hline $\begin{array}{c}\text { Př́spěvek nad rámec poskytovaného penzijního připojištění se státním } \\
\text { př́spěvkem }\end{array}$ & Individuálně (min. 300,-) & Individuálně (min. 600,-) & $\begin{array}{l}\text { Individuálnè } \\
(\min .1000,-)\end{array}$ \\
\hline $\begin{array}{l}\text { Cilové odměny za odvedení mimořádných výkonủ pro podnik } \\
\text { či zajištění mimořádnỵch výnosú }\end{array}$ & Individuálně (min. $3000,-)$ & Individuálně (min. $3000,-$ ) & $\cdots$ \\
\hline Odměny za dosažení prokazatelných úspor nákladủ podniku & $\begin{array}{l}\text { až do výše } 15 \% \text { ze } \\
\text { vzniklých úspor nákladủ } \\
\text { podniku }\end{array}$ & $\begin{array}{l}\text { až do výše } 15 \% \text { ze vzniklých } \\
\text { úspor nákladư podniku }\end{array}$ & -- \\
\hline Odměny za nulovou absenci zaměstnance během kalendářního roku & $6000,-$ & $5000,-$ & $-\cdots$ \\
\hline
\end{tabular}

Zdroj: Vlastní zpracování

\section{Finanční prostředky vynaložené na benefitní odměňování zaměstnanců podniku}

Modelová situace výrobního podniku DR, a. s. kalkuluje s 206 zaměstnanci. Ti jsou rozděleni do tří skupin (na základě prezentovaného klíče), přičemž nejpočetnější skupinu tvoří zaměstnanci „kategorie D“. Následné hodnocení pracovního přístupu zaměstnance a dalších parametrů jeho postoje $\mathrm{k}$ práci vyústilo $\mathrm{v}$ hodnocení př́slušným stupněm. Po přepočtu koeficienty a sazbou (v Kč) za jeden bod vzešel danému zaměstnanci peněžní obnos, s nímž může $\mathrm{v}$ rámci stanovených pravidel disponovat.

U nabízených benefitů v rámci PEVNÉHO bloku jsou stěžejní a nákladově nejvíce zatížené položky: penzijní připojištění se státním příspěvkem; soukromé životní pojištění; příspěvek na stravné (55\% ceny stravenky). Představují roční náklad ve výši 11000 až 14000 Kč na jednoho zaměstnance. V souhrnném vyjádření pak jde (u hodnotově vyčíslených benefitů ${ }^{11}$ ) o částku 2,4 až 2,9 mil. Kč připadající na pokrytí nákladů podniku v rámci systému jádra PEVNÝ blok. Je nutné kalkulovat i s náklady na další benefitní položky obsažené v tomto bloku, mající charakter využívání i pro soukromé účely (jedná se především o služební automobily pro představitele top managementu; mobilní telefony či notebooky pro top, střední a nižší management), a taktéž s náklady na úhradu dalších benefitů uvedených v „Přehledu nabízených zaměstnaneckých benefitů DR, a. s.“, přičemž u nich vlivem specifičnosti přesnou predikci není možné učinit (tzn., z důvodu specifičnosti uvedených benefitů u nich není vyčíslena konkrétní peněžitá výše v Kč).

Náklady spojené s vynaložením prostředků na první a druhou podskupinu VOLITELNÉHO bloku (u hodnotově vyčíslených benefitů) jsou predikovány ve výši 2,3 mil. až 2,5 mil. Kč.

\footnotetext{
${ }^{11}$ Hodnotově vyčíslenými benefity jsou míněny ty zaměstnanecké výhody, u nichž je v Přehledu nabízených zaměstnaneckých benefitů DR, a. s. uvedena konkrétní hodnota v Kč.
} 
Výše vynaložených prostř̌edků se odvíjí od počtu zaměstnanců zastoupených v jednotlivých skupinách (zaměstnanci „kategorie D“; „TH pracovníci + vybraní zaměstnanci kategorie D“; „představitelé top managementu“) a od zohlednění hodnocení příslušným stupněm a jejich následného odměnění. Dále je třeba kalkulovat s náklady spojenými s benefity první a druhé benefitní podskupiny volitelného bloku, u nichž není paušálně hodnota benefitů uvedena, přičemž jejich výše může být odlišná u každého zaměstnance (jde například o čerpání benefitu Sick Day, či benefitů třetí benefitní podskupiny, kde se jejich hodnotová výše odvíjí od rozhodnutí ředitele podniku - tedy je uplatňován individuální př́ístup k danému zaměstnanci. Další náklady jsou spojeny s čerpáním zaměstnaneckých výhod představiteli top managementu, přičemž hodnotová výše jednotlivých benefitních položek pro každého z nich se odvíjí taktéž od rozhodnutí ředitele DR, a. s.

Predikované celkové náklady spojené $\mathrm{s}$ poskytováním zaměstnaneckých výhod $\mathrm{v}$ rámci prezentovaného systému benefitního odměňování v podniku DR, a. s. se pohybují v rozmezí 5,0 až 6,5 mil. Kč. Výše vynaložených prostředků reflektuje aktuální situaci v legislativní oblasti (upravující poskytování benefitů zaměstnavatelem a čerpání benefitů zaměstnancem), př́ípadné změny $\mathrm{v}$ „odvodové pojistné politice“ a v neposlední řadě taktéž preference samotných zaměstnanců a finanční situaci (možnosti) daného podniku. Tyto skutečnosti předurčují absolutní výši sumy prostř̌edků, připadající za kalendářní rok na jednoho zaměstnance. Dle stanovených maximálních limitů lze u hodnotově vyčíslených benefitů pevného bloku, první a druhé podskupiny volitelného bloku vysledovat, že zaměstnanec „kategorie D“ má možnost za kalendářní rok dosáhnout na obnos prostředků v hodně až 30500 Kč $(14000+$ $2000+14500 \mathrm{Kč}), \mathrm{u}$ „TH pracovníka či vybraného zaměstnance kategorie D“ částku 52000 Kč $(14000+4000+34000$ Kč), u ,představitelů top managementu“ částku $14000+6000$ + částku odvíjející se od rozhodnutí ředitele podniku (tj. částku ve druhé benefitní podskupině volitelného bloku blíže nespecifikovanou z důvodu individuálního př́ístupu ředitele podniku ke každému z představitelů top managementu).

Čerpání benefitů př́ślušným pracovníkem podniku je možné za uplynulý kvartál, přičemž je na zvážení managementem podniku, jakou strategii zvolí pro další období - zda-li bude nadále zaměstnance odměňovat za čtvrtletí (kvartál), či přistoupí k odměňování za standardní měsíční období korespondující s jeho odvedeným pracovním výkonem a výměrem jeho mzdy. Při prrípadné změně hodnoceného období by přirozeně došlo také ke změně hodnot daných konkrétních benefitních položek, jež by měly tedy poměrově nižší peněžité hodnoty, přičemž by bylo nutné upravit (uzpůsobit) podmínky jejich čerpání na kalendářní měsíc. Výše zmíněným je demonstrativně nastíněna flexibilita možnosti hodnocení a možnost úprav nastavení tohoto systému, a to zejména volitelného bloku.

\section{Závěr}

Výše vynakládaných finančních prostředků do oblasti benefitního odměňování by měla reflektovat míru důležitosti, kterou přikládá management podniku lidskému kapitálu a investicím do něj. Snahou racionálně uvažujícího zaměstnavatele by mělo být udržení si kvalitního zaměstnance ve svém podniku, a to $\mathrm{i} \mathrm{z}$ důvodu, že ,náklady na nahrazení jednoho zaměstnance se odhadují na 40 až 150 \% jeho platu a je proto levnější do něj investovat. (Wain, 2010).

V článku je navrhována dílčí koncepce systému benefitního odměňování zaměstnanců ve výrobním podniku na principech cafeteria systému s jeho modifikací. Na modelové situaci 
středně velkého výrobního podniku je představena možnost flexibilního nastavení systému, odvíjející se od možnosti značné variantnosti nabízených řešení. V navrhované koncepci jsou skloubeny prvky podnikové odpovědnosti při čerpání benefitů (pevný blok) s prvky možnosti svobodné volby každého ze zaměstnanců (volitelný blok), přičemž výběr zaměstnaneckých výhod je rozčleněn do tři podskupin volitelného bloku, včetně možnosti poskytování mimořádných výhod plynoucích z určité zainteresovanosti konkrétního zaměstnance pro podnik. Systém čerpání benefitů vyžaduje dodržování určitých pravidel a plnění managementem stanovených kritérií hodnocení každým zaměstnancem podniku. Tímto je splněn požadavek společnosti na dodržování pravidel, přičemž toto akceptování umožňuje zaměstnanci následný výběr z obsáhlého portfolia benefitů a disponování s prostředky, jejichž výši má možnost každý z nich svým vlastním př́stupem a chováním ovlivnit. Systém benefitního odměňování je třeba nastavit tak, aby čerpání nabízených benefitů nebylo pro zaměstnance rutinním či obtěžujícím počinem bez ,přidané hodnoty“, ale naopak, aby bylo motivující, transparentní, efektivní a umocňovalo zaměstnancům pozitivní postoj k zaměstnavateli, dotvářelo podnikovou kulturu a zvyšovalo loajalitu každého pracovníka.

\section{Literatura:}

[1] ARMSTRONG, M. Odměňování pracovníků. 1. české vyd. Praha : Grada Publishing, 2009, 448 s. ISBN 978-80-247-2890-2.

[2] KOUBEK, J. Řízení lidských zdrojů. 4. vyd. Praha : Management Press, 2009, 399 s. ISBN 978-80-7261-168-3.

[3] PALA, M. Zaměstnanecké výhody v českých podnicích. Personál, 2002, roč. 8, č. 9, s. 10. ISSN 1213-8878.

[4] PELC, V. Zaměstnanecké benefity v roce 2009. Praha : Linde, 2009, 233 s. ISBN 978-807201-754-6.

[5] SMRČEKOVÁ, K. Sladění cílů firmy a potřeb zaměstnanců. [online]. Dostupné z: URL http://www.hrportal.cz/?sekce=3\&uroven=2\&obsah=0\&cid=114230, [cit. 4. 9. 2011].

[6] Vlastní výzkum a konzultace s představiteli managementu v rámci působení v podniku DR. a. s.

[7] WAIN, D. Investujte do lidí. Moderní řízení, 2010, roč. 45, č. 1, s. 57. ISSN 0026-8720.

Klasifikace JEL: J32, M12

\section{Ing. Radim řihák}

Slezská univerzita v Opavě

Obchodně podnikatelská fakulta v Karviné

Katedra společenských věd

Univerzitní nám. 1934/3

73340 Karviná, ČR

rihak@opf.slu.cz 